Rev. Bras. Saúde Prod. Anim., Salvador, v.19, n.3, p.277-286 jul./set., 2018 http://dx.doi.org/10.1590/S1519-99402018000300005

\title{
Gas production and in vitro degradability of sheep diets containing propolis ethanolic extract
}

\author{
Efeito do extrato etanólico de própolis sobre a produção de gases e degradabilidade in \\ vitro de dietas para ovinos
}

\author{
ARAUJO, Cintia Mirely de ${ }^{1}$; SILVA, Fernanda Gomes Bezerra da ${ }^{2}$; CASTRO, Daniela \\ Pionório Vilaronga ${ }^{3}$; MENEZES, Daniel Ribeiro ${ }^{4}$; QUEIROZ, Mário Adriano Ávila ${ }^{5}$; \\ YAMAMOTO, Sandra Mari ${ }^{5^{*}}$
}

\footnotetext{
${ }^{1}$ Universidade Federal da Paraíba, Centro de Ciências Agrárias, Pós-Graduação em Zootecnia, Areia, Paraíba, Brasil.

${ }^{2}$ Universidade Federal do Vale do São Francisco, Pós-Graduação em Ciência Animal, Petrolina, Pernambuco,Brasil.

${ }^{3}$ Universidade Federal da Bahia, Escola de Medicina Veterinária e Zootecnia, Pós-Graduação em Zootecnia, Salvador, Bahia, Brasil.

${ }^{4}$ Universidade Federal do Vale do São Francisco, Campus Ciências Agrárias, Colegiado de Zootecnia, Petrolina, Brasil.

${ }^{5}$ Universidade Federal do Vale do São Francisco, Campus Ciências Agrárias, Colegiado de Medicina Veterinária, Petrolina, Brasil.

*Endereço para correspondência: sandramariy@gmail.com
}

\section{SUMMARY}

This study evaluated the influence of the propolis ethanolic extract (PEE) on gas production and in vitro degradability of sheep diets. Five experimental diets (treatments) were evaluated: without addition of PEE; $6 \mathrm{~mL}$ PEE; $12 \mathrm{~mL}$ PEE; $24 \mathrm{~mL} \mathrm{PEE}$ and $36 \mathrm{~mL} \mathrm{PEE} / \mathrm{kg}$ concentrate. The experimental diet consisted of $50 \%$ elephant grass (Pennisetum purpureum) and 50\% concentrate. There was a quadratic effect $(\mathrm{P}<0.05)$ for the volumes of total gas production $(\mathrm{Vt})$, gases produced by the rapid degradation fractions (Vf1), and for in vitro degradability at 120 hours (Deg120), where the lowest values of Vt, Vfl and Deg120, were found for the inclusion of $9.4 \mathrm{~mL}$ $\mathrm{PEE} / \mathrm{kg}$ concentrate. Gas production by fermentation of the slow degradation fraction (Vf2) presented a mean of $25 \mathrm{~mL} / \mathrm{g} \mathrm{DM}(\mathrm{P}<0.05)$. The colonization time of food particles $(K)$ significantly reduced $(\mathrm{P}<0.05)$ with increasing inclusion of PEE. Thus, it can be concluded that the PEE up to the inclusion of $9.4 \mathrm{~mL} / \mathrm{kg}$ concentrate was efficient in inhibiting in vitro total gas production and from the fractions of rapid degradation by 9.9 and $15.3 \%$, respectively, in addition to promoting a reduction of $5.3 \%$ in degradability after $120 \mathrm{~h}$ incubation in diets with a concentrate: forage ratio of 50:50. Thus, the inhibition in gas production was proportionally greater than the reduction of degradability.

Keywords: colonization time, degradation, fermentation

\section{RESUMO}

Objetivou-se com este estudo avaliar se a produção de gases e a degradabilidade in vitro de dietas para ovinos podem ser influenciadas pelo uso do extrato etanólico de propólis.Foram avaliados cinco níveis de inclusão do extrato etanólico de própolis (EEP) nas dietas, sendo: sem adição de EEP; $6 \mathrm{~mL}$ de EEP; $12 \mathrm{~mL}$ de EEP; 24 $\mathrm{mL}$ EEP e $36 \mathrm{~mL}$ de EEP/kg de concentrado, sendo a dieta experimental constituída de $50 \%$ de capim elefante triturado (Pennisetum purpureum) como volumoso e $50 \%$ de concentrado (milho, farelo de soja e núcleo mineral e vitamínico). Houve efeito quadrático $(\mathrm{P}<0,05)$ para os volumes de produção de gases total $(\mathrm{Vt})$,gases produzidos pelas frações de degradação rápida $\left(\mathrm{Vf}_{1}\right)$ e para a degradabilidade in vitro em 120 horas (Deg120), onde os menores valores de Vt, Vfl e Deg120, foram encontrados para a inclusão aproximada de $9 \mathrm{~mL}$ de EEP/Kg de concentrado, representando, $79,85(\mathrm{Vt})$ e 55,08 (Vfl) $\mathrm{mL} / \mathrm{g}$ de $\mathrm{MS}$, e $79,14 \%$ de degradabilidade. Já produção de gás pela fermentação da fração de degradação lenta $\left(\mathrm{Vf}_{2}\right)$ não foi significativo $(\mathrm{P}<0,05)$, com média de 25 $\mathrm{mL} / \mathrm{g}$ MS. O tempo de colonização das partículas do alimento $(\kappa)$ reduziu significativamente $(\mathrm{P}<0,05)$ com o aumento dos níveis de inclusão do EEP. Sendo assim, é possível concluir que o extrato etanólico de própolis até a inclusão de 9,4 $\mathrm{mL} / \mathrm{Kg}$ de concentrado foi eficiente em inibir in vitro a produção de gases total $(\mathrm{Vt})$ e a partir das frações de degradação rápida (Vf1)em 9,9 e 
$15,3 \%$, respectivamente, além de promover uma redução de 5,3\% na degradabilidade após $120 \mathrm{~h}$ de incubação (Deg120h), em dietas com proporção concentrado:volumoso de 50:50. Assim, a inibição na produção de gases foi proporcionalmente superior a redução da degradabilidade.

Palavras-chave: degradação, fermentação, tempo de colonização

\section{INTRODUCTION}

The management of the ruminal environment is carried out in order to increase the efficiency of food degradation, reducing the energy losses, mainly occurring in the processes of gas production and nitrogen recycling (SILVA et al., 2015).

One way to modify the rumen environment is the use of antimicrobials that act by reducing the number of grampositive bacteria (producing methane and $\mathrm{CO}_{2}$ ) and consequently favoring the growth of gram-negative producers of propionic acid, organic acid of higher energy potential, thus generating productive gains (STRADIOTTI JUNIOR et al., 2004a).

However, the use of antimicrobials, such as ionophores and anticoccidials, has been related to the increase in the transfer of resistance genes (WALLACE, 2004). In addition, the consumers are increasingly demanding, with great rejection of products from animals fed antibiotics, with the European Union banning the use of ionophores as of January $1^{\text {st }}, 2006$ (EU Resolution 1831/2003). For this reason, many studies have been conducted to find natural substances that can replace antimicrobials in a satisfactory manner, improving the ruminant feed efficiency without leaving residues in their products (VALERO et al., 2011).

Propolis is the product of the mixture of resin collected from plants by bees and salivary secretions thereof (SOLTAN et al., 2015) and its chemical composition is intrinsically related to the ecological and floristic characteristics of the environment in which the material was collected (AGUIAR et al., 2014; MORSY et al., 2015). Thus, considering that Caatinga is an exclusively Brazilian biome, home to endemic plants, which in general are rich in phenolic compounds (STRAUSSDEBENEDETTI, 1996), resin collected from these plants will also have greater abundance of these substances.

Among their several bioactive properties, phenols present antibacterial (mainly in gram-positive bacteria) and anti-protozoa (PRADO et al., 2010; WAGH, 2013) activities. Thus, in the rumen these compounds have the power to reduce the population of protozoa, with consequent reduction in the production of gases, by the decrease in the production of $\mathrm{H}^{+}$ions (WANG et al., 2009; BHATTA et al., 2013), in this way, propolis, because it contains a large amount of these compounds, may act as a possible substituent for the ionophores.

In view of the above, the objective of this study was to evaluate the influence of the propolis ethanolic extract on gas production and in vitro degradability of sheep diets.

\section{MATERIAL AND METHODS}

The experimental test was carried out at the Laboratory of Animal Requirement and Metabolism, Agricultural Sciences Campus, Federal University of the Vale do São Francisco (Univasf), in the city of Petrolina, State of Pernambuco, Brazil. The research was approved by the Ethics Committee on Human and Animal Studies/Univasf, under the protocol number 0040/190811.

Crude propolis was obtained from beekeeper associations in the region of 
the São Francisco Valley. After the reception, the propolis underwent a cleaning process to remove wax residues and other impurities.

To obtain the propolis ethanolic extract, $30 \mathrm{~g}$ propolis was added with $100 \mathrm{~mL}$ ethanolic solution $(70 \mathrm{v} / \mathrm{v})$, according to the methodology described by Stradiotti JUNIOR. et al. (2004). After 10 days, the extract was filtered through filter paper to obtain 30\% propolis ethanolic extract (PEE), which contained $0.3 \mathrm{~g} / \mathrm{mL}$ propolis substances. In this study, qualitative analyses were carried out according to the Technical Regulation of Propolis Quality and Identity (BRASIL, 2001), where the presence of flavonoid phenolic compounds, more specifically naringenin and apigenin, was identified by high performance liquid chromatography.
Five levels of inclusion of the propolis ethanolic extract (PEE) were evaluated, namely: control - without addition of PEE; $6 \mathrm{~mL}$ PEE $(1.8 \mathrm{~g} / \mathrm{mL}$ propolis substances); $12 \mathrm{~mL}$ PEE (3.6 g/mL propolis substances); $24 \mathrm{~mL}$ PEE (7.2 $\mathrm{g} / \mathrm{mL}$ propolis substances); $36 \mathrm{~mL}$ $\mathrm{PEE} / \mathrm{kg}$ concentrate $(10.8 \mathrm{~g} / \mathrm{mL}$ propolis substances).

Propolis ethanolic extract was added to the incubation fluid respecting a ratio with the amount of concentrate used in the diet. The experimental diet consisted of $50 \%$ forage (crushed elephant grass Pennisetum purpureum) and 50\% concentrate (corn, soybean meal and mineral and vitamin nucleus), as shown in Table 1, formulated according to the recommendations of the NRC (2007) for adult sheep maintenance.

Table 1. Chemical composition of the forage (Pennisetum purpureum), concentrate and the experimental feed

\begin{tabular}{lccc}
\hline Chemical Composition & Elephant grass & Concentrate & Diet \\
\hline Dry Matter $^{1}$ & 281.1 & 924.2 & 602.7 \\
Organic Matter $^{2}$ & 900.9 & 921.1 & 911.0 \\
Ash $^{2}$ & 99.1 & 78.9 & 89.0 \\
CrudeProtein $^{2}$ & 54.9 & 215.6 & 135.2 \\
Neutral DetergentFiber $^{2}$ & 688.4 & 408.2 & 548.3 \\
Acid Detergent Fiber $^{2}$ & 417.3 & 65.4 & 241.3 \\
Hemicellulose $^{2}$ & 271.1 & 342.8 & 307.0 \\
\hline
\end{tabular}

${ }^{1} \mathrm{~g} / \mathrm{Kg}$ Natural Matter; ${ }^{2} \mathrm{~g} / \mathrm{Kg}$ Dry Matter; ${ }^{\mathrm{cp}}$ Corrected for ash and protein.

Samples of forage, concentrate and complete diet were dried at $55^{\circ} \mathrm{C}$ and ground in a Wiley mill using a $1 \mathrm{~mm}$ sieve, and then analyzed according to the Association of Official Analytical Chemists (AOAC, 1997) for determination of dry matter (DM) (method 920.39), crude protein (CP) (method 954.01), ether extract (EE) (method 920.39), and ash (method 942.05).

The determination of neutral detergent fiber (NDF) and acid detergent fiber (ADF) was performed according to the methodology proposed by Van Soest et al. (1991), using the ANKOM fiber analyzer (ANKOM200 Fiber Analyzer ANKOM Technology Corporation, Fairport, NY, USA). The NDF was corrected for ash and protein, where the residues from neutral and acid detergent fibers digestion were incinerated at $600^{\circ} \mathrm{C}$ for 4 hours, and the correction for protein was performed by neutral and aciddetergent insoluble protein (DETMANN, 2012).

Ruminal fluid was taken from a sheep cannulated in the rumen, adapted with 
corn and soybean meal concentrate, and fresh elephant grass (Pennisetum purpureum) in a diet with a concentrate: forage ratio of 50:50. The ruminal fluid was collected, filtered through 4 layers of cheesecloth and kept in a thermos bottle heated at $39^{\circ} \mathrm{C}$ with $\mathrm{CO}_{2}$ injection, and was taken to the laboratory, where $\mathrm{CO}_{2}$ injection and temperature control were maintained.

In order to determine the total gas production and the kinetic parameters of ruminal fermentation, we used the semiautomated in vitro technique described by Mauricio et al. (2003).

As substrate for incubation, we weighed approximately $0.5 \mathrm{~g}$ crushed elephant grass, as forage, and $0.5 \mathrm{~g}$ concentrate (used in the incubations as control and with the different proportions of PEE), totalizing $1 \mathrm{~g}$ substrate per vial. Samples were placed in tissue bags made of $100 \%$ polyester, with a pore size of $50 \mu \mathrm{m}$.

Seven Styrofoam boxes were used, each containing 4 glass vials per treatment and 2 blanks, containing only the ruminal fluid and the culture medium (buffer), used as control, for comparison, totaling 154 vials. The flasks were added with 90 $\mathrm{mL}$ McDougall (1948) buffer solution, previously reduced with $\mathrm{CO} 2(\mathrm{pH} 6.9$ 7.0), $10 \mathrm{~mL}$ ruminal fluid kept under $\mathrm{CO}_{2}$ spray and the bags containing the substrates. The vials were sealed with rubber stoppers, being shaken manually and placed in an air-conditioned room at $39^{\circ} \mathrm{C}$, where they were shaken every 2 hours.

The pressure, in psi (Pound per Square inch), caused by gases accumulated in the upper part of the vials, was measured by means of a pressure transducer connected at its end to a needle $(0.6 \mathrm{~mm})$.

The pressure readings were taken at the following incubation times: 2, 4, 6, 8, 9, $11,12,14,17,20,24,28,34,48,72,96$ and 120 hours, from the needle insert in the rubber stoppers.

With the sum of the gas volume for each reading time, the cumulative gas production curves were produced. The cumulative gas production kinetics was analyzed using the bicompartmental logistic model proposed by Schofield et al. (1994):

$\mathrm{V}(\mathrm{t})=\frac{\mathrm{Vf}_{1}}{1+\mathrm{e}^{[2-4 k[(\mathrm{t}-K)]}}+\frac{\mathrm{Vf}_{2}}{1+\mathrm{e}^{[2-4 k 2(\mathrm{t}-K)]}}$

Where: $\mathrm{V}(\mathrm{t})=$ cumulative volume $(\mathrm{mL})$ at time $\mathrm{t} ; \mathrm{Vf}_{1}=$ volume of gases produced by the rapid degradation fractions $(\mathrm{mL} / \mathrm{g} \mathrm{DM}) ; \mathrm{Vf}_{2}=$ volume of gases produced by the slow degradation fractions $(\mathrm{mL} / \mathrm{g} \mathrm{DM}) ; \mathrm{k}=$ Specific degradation rate $(\% / \mathrm{h}) ; \mathrm{k} 1=$ specific degradation rate of rapid digestion fractions $(\% / h)$; - Specific degradation rate of slow digestion fractions $(\% / \mathrm{h}) ; \mathrm{t}$ $=$ fermentation time; $\Lambda=$ time of colonization of bacteria $(\mathrm{h})$.

The design was completely randomized with five treatments and four replicates. The results were analyzed by Statistical Analysis System version 9.1 (SAS, 2003), and the normality of the residues was checked by the SHAPIRO-WILK test (PROC UNIVARIATE) and the variances were compared by orthogonal contrasts with a significance level of 5\% by PROC GLM. As the levels were not equidistant between levels of propolis, the PROC IML was used to generate the vectors of each contrast, the data wassubjected to regression analysis and the differences compared at 5\% level of significance.

\section{RESULTS AND DISCUSSION}

There was an effect of the inclusion of PEE for the variables volume of gas production $(\mathrm{Vt})$, volume of gases produced by the rapid degradation fractions (Vf1), colonization time $(K)$ and in vitro gas degradability within 120 hours (Table 2; $\mathrm{P}<0.05$ ). For the total and produced volume of gases by the rapid degradation fractions, it is possible to 
observe a quadratic effect with minimum points of 8.95 and $9.125 \mathrm{~mL} \mathrm{PEE} / \mathrm{kg}$ concentrate respectively, representing volumes of gas production at $79.85 \mathrm{~mL} / \mathrm{g}$ dry matter (DM), total and $55.08 \mathrm{~mL} / \mathrm{g}$ $\mathrm{DM}$ for the rapid degradation fractions, which was equivalent to a reduction of $9.95 \%$ in the total gas production in relation to the control diet Figure 1).

The quadratic effect found for total gas production (Vt) (Figure 2) was influenced by the result found for the production of gases from the rapid degradation fractions (Vf1), since the result for the gas production from the slow degradation fractions was not influenced by dietary PEE levels. Thus, gas production reduced to the level of approximately $9 \mathrm{~mL}$ $\mathrm{PEE} / \mathrm{kg}$ concentrate, after this level occurred the increase in gas production.

In vitro degradability after 120 hours incubation showed a quadratic result (Table 2, Figure 2, $\mathrm{P}<0.05$ ), with a minimum point for $9.4 \mathrm{~mL} \mathrm{PEE} / \mathrm{kg}$ concentrate, equivalent to $79.14 \%$ degradation of the substrate, after this level the degradability increased. This result was not expected since the majority of studies showed a linear reduction in gas production with the use of PEE, since it inhibits proteolytic and gram-positive bacteria (OLIVEIRA et al., 2004; STRADIOTTI JUNIOR et al., 2004b; PAULA et al., 2016), the main microorganisms that release carbon and hydrogen, as fermentation products, which are used by methanogenic bacteria to produce methane. The reduction in gas production occurred due to a possible reduction of the activity of the bacteria responsible for degrading the rapid digestion fractions, a result that is not in accordance with the literature, since according to Soltan et al. (2015), the propolis acts more intensely on the grampositive bacteria, which are usually related to the degradation of the slow digestion fractions, having as representatives some cellulolytic and hemicellulolytic bacteria.

Table 2. Maximum production potential and production rate of gases $(\mathrm{mL} / \mathrm{g} \mathrm{DM})$, microbial colonization time $(\mathrm{h})$ and in vitro gas degradability (\%) in diets containing different PEE levels

\begin{tabular}{|c|c|c|c|c|c|c|c|c|}
\hline \multirow{2}{*}{ Parameters } & \multicolumn{5}{|c|}{ PEE levels (mL/Kg concentrate) } & \multirow{2}{*}{ SEM* } & \multicolumn{2}{|c|}{ Effect** } \\
\hline & 0 & 6 & 12 & 24 & 36 & & Lin. & Quad. \\
\hline $\mathrm{Vt}(\mathrm{mL})^{1}$ & 88.43 & 81.40 & 77.73 & 82.81 & 81.87 & 1.02 & NS & 0.0066 \\
\hline $\mathrm{Vf}_{1}(\mathrm{~mL})^{2}$ & 65.14 & 55.71 & 53.35 & 56.59 & 55.67 & 1.14 & 0.0141 & 0.0030 \\
\hline $\mathrm{Vf}_{2}(\mathrm{~mL})$ & 23.28 & 25.69 & 24.38 & 26.21 & 26.19 & 0.52 & NS & NS \\
\hline $\mathrm{k}(\% / \mathrm{h})$ & 0.086 & 0.086 & 0.080 & 0.080 & 0.083 & 0.001 & NS & NS \\
\hline $\mathrm{k} 1(\% / \mathrm{h})$ & 0.074 & 0.074 & 0.067 & 0.067 & 0.071 & 0.001 & NS & NS \\
\hline $\mathrm{k} 2(\% / \mathrm{h})$ & 0.012 & 0.013 & 0.013 & 0.012 & 0.012 & 0.0001 & NS & NS \\
\hline$\Lambda(h)^{3}$ & 10.45 & 9.78 & 9.65 & 9.84 & 9.61 & 0.095 & 0.0158 & NS \\
\hline Deg48h (\%) & 66.82 & 66.86 & 66.50 & 67.44 & 68.28 & 0.38 & NS & NS \\
\hline Deg120h $(\%)^{4}$ & 83.57 & 79.71 & 78.85 & 80.63 & 79.10 & 0.43 & 0.0004 & 0.0019 \\
\hline
\end{tabular}

$\mathrm{PEE}=$ propolis Ethanolic Extract; Vt $=$ volume of gas produced by rapid and slow degradation fractions; Vf1 = volume of gas produced by the rapid degradation fractions (soluble sugars and starch);Vf2 = volume of gas produced by slow degradation fractions (cellulose and hemicellulose); $\mathrm{k}=$ specific rate of degradation of rapid and slow digestion fractions; $\mathrm{k} 1$ = specific rate of degradation of rapid digestion fractions; $\mathrm{k} 2$ = specific rate of degradation of slow digestion fractions; $\Lambda$ - colonization time; Deg48h = in vitro gas degradability within 48 hours; Deg120 = in vitro gas degradability within 120 hours (Deg120). Significant $\mathrm{P}<0.05$. *Standard error of the mean. **Regression equation, orthogonal polynomial test, linear or quadratic response.

${ }^{1} \hat{\mathrm{Y}}=88.68-1.97 \mathrm{x}+0.11 \mathrm{x}^{2},\left(\mathrm{R}^{2}=0.59\right) ;{ }^{2} \hat{\mathrm{Y}}=65.07-2.19 \mathrm{x}+0.12 \mathrm{x}^{2},\left(\mathrm{R}^{2}=0.67\right) ;{ }^{3} \hat{\mathrm{Y}}=10.43-$ $0.15 \mathrm{x},\left(\mathrm{R}^{2}=0.53\right) ;{ }^{4} \hat{\mathrm{Y}}=83.56-0.94 \mathrm{x}+0.05 \mathrm{x}^{2},\left(\mathrm{R}^{2}=0.82\right)$. 


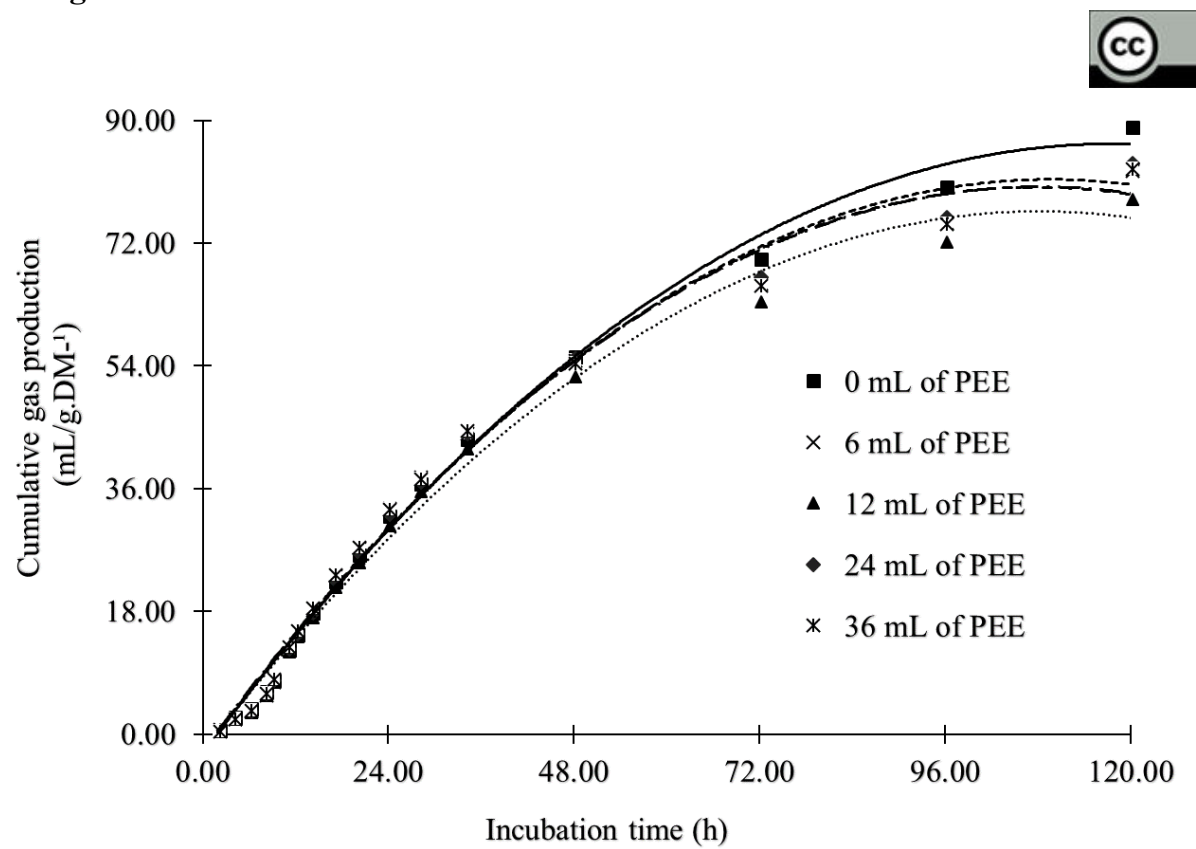

Figure1. Cumulative gas production $\left(\mathrm{mL} / \mathrm{g} \cdot \mathrm{DM}^{-1}\right)$ of diets containing different levels of PEE at the end of 120 hours of incubation. Regression equation: $\hat{\mathrm{Y}}=88.68-1.97 \mathrm{x}+0.11 \mathrm{x}^{2}\left(\mathrm{R}^{2}=0.59\right)$

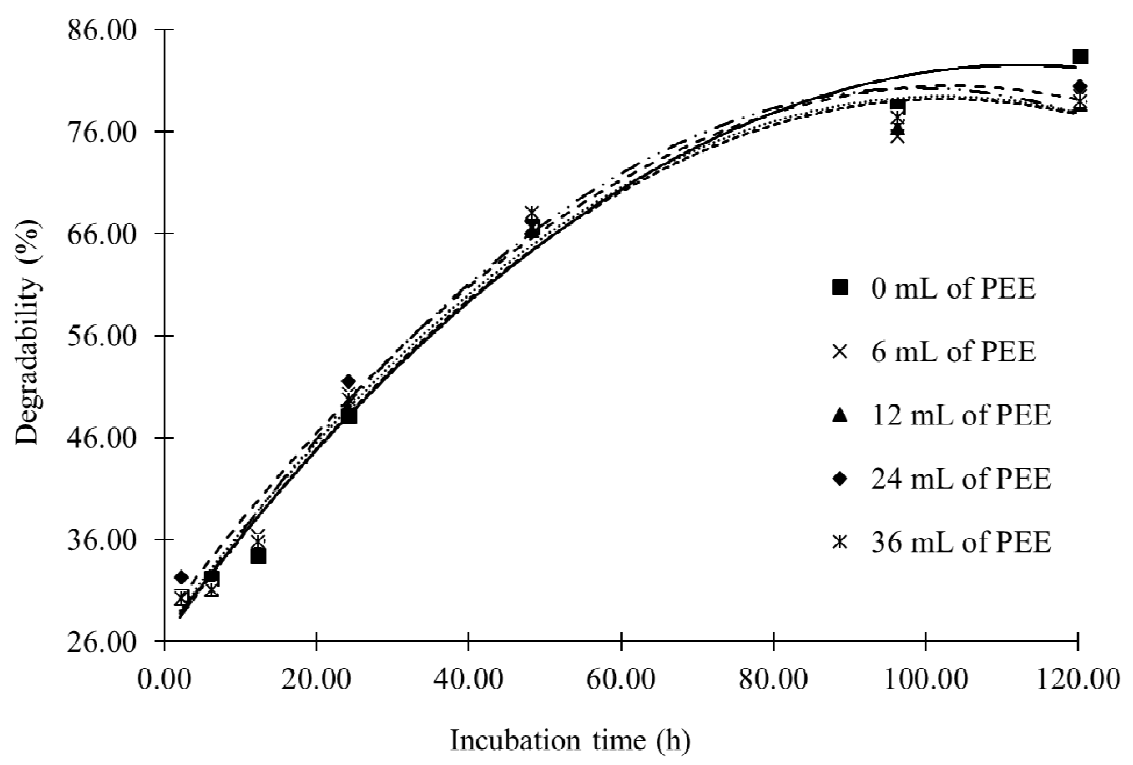

Figure 2. In vitro degradability of dry matter of diets containing different levels of PEE at the end of 120 hours of incubation. Regression equation: $\hat{\mathrm{Y}}=83.56-0.94 \mathrm{x}+0.05 \mathrm{x}^{2}\left(\mathrm{R}^{2}=0.82\right)$

According to Heimbach et al. (2014), in in vitro situations, the short chain fatty acids (SCFA) react with the buffer used (bicarbonate) to release $\mathrm{CO}_{2}$ in the medium, so gas production occurs simultaneously with the fiber digestion, i.e. the higher the degradation, the higher the gas production and this would explain the increase in the production of gases after the indicated minimum point. However, this result could also be related to the occurrence of alcoholic fermentation in the rumen, which usually occurs by the activity of 
fungiusing hemicellulose with the aid of xylose isomerase enzyme, releasing $\mathrm{CO}_{2}$ gas as a product (COLOMBO et al., 2017).

Another factor to consider is the law of diminishing returns described by Lana et al. (2005). Based on the saturation kinetics model of enzyme systems of Michaelis-Menten, the law of diminishing returns states that the biological responses to the supplied substrates reduce with increasing concentration of this, due to reaching a biological limit of use. Therefore, the increase of over $9 \mathrm{~mL}$ $\mathrm{PEE} / \mathrm{kg}$ concentrate causes harm to the ruminal environment, not promoting gains in nutrient utilization efficiency.

There was no significant effect of the inclusion of PEE levels on the gas production variables from the slow degradation fractions (Vf2) and specific rates of total degradation $(\mathrm{k})$, of the fast $(\mathrm{k} 1)$ and slow $(\mathrm{k} 2)$ digestion fractions, as well as for the degradability at 48 hours incubation (Deg48).

The time of colonization of food particles $(K)$ significantly reduced $(P$ $<0.05)$ with increasing PEE inclusion levels, a reduction of about $1.43 \%$ for each $\mathrm{mL}$ of PEE included. This reduction is an unexpected result, since according to Berchielli et al. (2006), the first microorganisms to colonize the food particle are fungi, opening space for bacterial colonization.

Propolis has an effect on fungi, which would cause a reduction of fungi in the medium, making bacterial colonization difficult; besides that, propolis plays a bacteriostatic role on gram-positive and some gram-negative bacteria (DIAS et al., 2012). Then increasing the inclusion of PEE should reduce the metabolism of these bacteria, increasing the colonization time. Thus, reduction in colonization time $(\kappa)$, found in this study, can be explained by the selection of more resistant bacteria, with more rapid metabolism, which consequently proliferate in the food particle more rapidly.

It is possible to observe a relationship between the results of total gas production and the rapid degradation fraction, where there is a reduction of degradation together with the gas production, which corroborates the explanation previously given, that the increase in degradation increases the amount of substrates used by methanogenic bacteria to produce gases.

The results obtained herein demonstrate that the ruminal microorganisms are able to adapt to the presence of large amounts of compounds from the PEE, reducing the ability of this extract to modulate ruminal fermentation and showing that small concentrations are enough to cause the desired effects.

The propolis ethanolic extract up to the inclusion of $9.4 \mathrm{~mL} / \mathrm{kg}$ concentrate was efficient in inhibiting in vitro total gas production $(\mathrm{Vt})$ and from the fractions of rapid degradation (Vf1) by 9.9 and $15.3 \%$, respectively, in addition to promoting a reduction of $5.3 \%$ in degradability after $120 \mathrm{~h}$ of incubation (Deg120h), in diets with a concentrate: forage ratio of 50:50. Thus, the inhibition in gas production was proportionally greater than the reduction of degradability.

\section{REFERENCES}

AGUIAR, S.C., PAULA, E.M., YOSHIMURA, E.H., SANTOS, W.B.R., MACHADO, E., VALERO, M.V., SANTOS, G.T. ZEOULA, L.M. Effects of phenolic compounds in propolis on digestive and ruminal parameters in dairy cows. Revista Brasileira de Zootecnia, v.43, n.4 p.197-206, 2014. 
ASSOCIATION OF OFFICIAL ANALYTICAL CHEMISTS - AOAC. Official methods of analysis. 16th ed. Arlington, VA, 1997.

BERCHIELLI, T.T.; PIRES, A.V.; OLIVEIRA, S.G. Nutrição de ruminantes. Jaboticabal, SP: FUNESP, 2006. 583p.

BHATTA, R.; SARAVANAN, M.; BARUAH, L.; SAMPATH, K.T, PRASAD, C.S. Effect of plant secondary compounds on in vitro methane, ammonia production and ruminal protozoa population. Journal of applied microbiology, v.115, n.2, p.455-465, 2013.

BRASIL. Ministério da Agricultura, Pecuária e do Abastecimento. Instrução

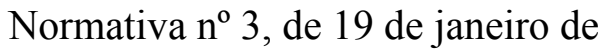
2001. Aprova os regulamentos Técnicos de Identidade e Qualidade de Apitoxina, Cera de Abelha, Geléia Real, Geléia Real Liofilizada, Pólen Apícola, Própolis e Extrato de Própolis, conforme consta dos Anexos desta Instrução Normativa. Diário Oficial da União, 2001. Seção 1, p.18.

COLOMBO, G.S.; MENDES, I.V.; SOUTO, B.M.; PARACHIN, N.; ALMEIDA, J.R.; QUIRINO, B.F. Descoberta de novos genes de xilose isomerase em rúmen de cabras brasileiras. In: ENCONTRO DE PESQUISA E INOVAÇÃO DA EMBRAPA AGROENERGIA, 2017, Brasília, DF. Anais... Brasília, DF: EMBRAPA, 2017.

DETMANN, E. Métodos para análise de alimentos. Visconde do Rio Branco, MG: Suprema, 2012. 214p.
DIAS, L.G.; PEREIRA. A.P.; ESTEVINHO, L.M. Comparative study of different Portuguese samples of propolis: Pollinic, sensorial, physicochemical, microbiological characterization and antibacterial activity. Food and Chemical Toxicology, v.50, n.12, p.4246-4253, 2012.

HEIMBACH, N.S.; ÍTAVO, C.C.B.F.; ÍTAVO, L.C.V.; FRANCO, G.L.; LEAL, C.R.B.; LEAL, E.S.; SILVA, P.C.G.; REZENDE, L.C.; SILVA, J.A. Resíduo da extração de própolis marrom na dieta de ruminantes: Digestibilidade e produção de gás in vitro. Archivos de Zootecnia, v.63, n.242, p.260, 2014.

LANA, R.P.; GOES, R.H.T.B.; MOREIRA, L.M.; MÂNCIO, A.B.; FONSECA, D.M.; TEDESCHI, L.O. Application of Lineweaver-Burk data transformation to explain animal and plant performance as a function of nutrient supply. Livestock Production Science, v.98, p.219-224, 2005.

MAURICIO, R.M.; PEREIRA, L.G.R.; GONÇALVES, L.C.; RODRIGUEZ, N.M.; MARTINS, R.G.R.;

RODRIGUES, J.A.S. Potencial da Técnica in vitro Semi-automática de produção de gases para a avaliação de silagens de Sorgo (Sorghum bicolor (L.) Moench). Revista Brasileira de Zootecnia, v.32, n.4, p.1013-1020, 2003.

McDOUGALL, E.I. Studies on ruminant saliva. 1 . The composition and output of sheep's saliva. Biochemical Journal, v.43, p.99-109, 1948. 
MORSY, A.S.; SOLTAN, Y.A., SALLAM, S.M.A., KREUZER, M., ALENCAR, S.M.;ABDALLA, A.L. Comparison of the in vitro efficiency of supplementary bee propolis extracts of different origin in enhancing the ruminal degradability of organic matter and mitigating the for- mation of methane.

Animal Feed Science and Technology, v.199, p.51- 60, 2015.

NATIONAL RESEARCH COUNCIL NRC. Nutrient requirement of Small ruminants. 1.ed. Washington: NAP, 2007.362p.

OLIVEIRA, J.S.; LANA, R.P.; BORGES, A.C.; QUEIROZ, A.C.; ALMEIDA, I.C.C. Efeito da Monensina e Extrato de Própolis sobre a produção de amônia e Degradabilidade in vitro da Proteína Bruta de diferentes fontes de Nitrogênio. Revista Brasileira de Zootecnia, v.33, n.2, p.504-510, 2004.

PAULA, E.M.; SAMENSARI, R.B.; PEREIRA, L.M.; MAIA, F.J.; YOSHIMURA, E.K.; FRANZOLIN, R.; FACIOLA, A.P.; ZEOULA, L.M. Effect $s$ of phenolic compounds on ruminal protozoa population, ruminal fermentation, and digestion in water buffaloes. Livestock Science, v.185, p.136-141, 2016.

PRADO, O. P.P.; ZEOULA, L.M.; PONTARA, L.P.M.; FRANCO, S.L.; NOVELLO, C.R.; GERON, L.J.V. Adição de Própolis ou Monensina Sódica sobre digestibilidade in vitro da matéria seca. Revista Brasileira de Saúde e Produção Animal [online], v.11, n.4, p.1023-1032, 2010.

RESOLUÇÃO DA UNIÃO EUROPÉIA (UE). Regulamento (CE) - $\mathbf{N}^{\circ}$

1831/2003. Relativo a aditivos destinados a alimentação animal, 2003.
SCHOFIELD, P.; PITT, R.E.; PELL, A.N. Kinetics of fiber digestion from in vitro gas production. Journal of Animal Science, v.72, n.11, p.2980-2991, 1994.

SILVA, F.G.B.; YAMAMOTO, S.M.; SILVA, E.M.S.; QUEIROZ, M.A.A.; GORDIANO, L.A.; FORMIGA, M.A. Propolis extract and sodium monensin on ruminal fermentation and hematological parameters in sheep. Acta Scientiarum. Animal Sciences, v.37, n.3, p.273-280, 2015.

SOLTAN, Y. A.; MORSY, A. S.; SALLAN, S. M. A.; HASHEM, N. M.; ABDALLA, A. L. Propolis as natural fed additive in ruminant diets; can propolis affect theruminants performance? (Review article). In: INTERNATIONAL CONFERENCE ON THE MODERN APPROACHES IN LIVESTOCK'S PRODUCTION SYSTEM, 2., 2015, Alexandria, Egito. Proccengins... Alexandria, Egito, 2015.

STRADIOTTI JUNIOR, D.; QUEIROZ, A.C.; LANA, R.P.; PACHECO, C.G.; EIFERT, E.C.; NUNES, P. M. M. Ação da Própolis sobre a desaminação de aminoácidos e a fermentação ruminal. Revista Brasileira de Zootecnia, v.33, n.4, p.1086-1092, 2004a.

STRADIOTTI JUNIOR, D.; QUEIROZ, A.C.; LANA, R.P.; PACHECO, C.G.; CAMARDELLI, M.M.L.; DETMANN, E.; EIFERT, E.C.; NUNES, P.M.M.; OLIVEIRA, M.V.M. Ação do Extrato de Própolis sobre a fermentação in vitro de diferentes alimentos pela técnica de produção de gases. Revista Brasileira de Zootecnia, v.33, n.4, p.1093-1099, 2004b. 
STRAUSS-DEBENEDETTI, S.;

BAZZAZ, F. Photosynthetic

characteristics of tropical trees along successional gradients. In: Mulkey, S.S.;

Chazdon, R.L.; Smith, A.P. (Eds.)

Tropical forest plant ecophysiology.

New York, Chapman e Hall, 1996. p.162186.

VALERO, M.V.; ZAWADZKI, F.;

FRANÇOSO, M.C.; FARIAS, M.S.;

ROTTA, P.P.; PRADO, I.N.;

VISANTAINER, J.V.; ZEOULA, L.M.

Sodium Monensin or propolis extract in the diet of crossbred (1/2 Red Angus vs.

$1 / 2$ Nelore) bulls finished in feedlot:

chemical composition and fatty acid profile of the Longissimus muscle.

Semina: CiênciasAgrárias, v.32, n.4, p.1617-1626, 2011.

VAN SOEST, P. J.; ROBERTSON, J. B.; LEWIS, B. A. Methods for dietary fiber, neutral detergent fiber, and nonstarch polysaccharides in relation to animal nutrition. Journal of dairy science, v.74, n.10, p.3583-3597, 1991.

WAGH, V.D. Propolis: a wonder bees product and its pharmalogical potentials. Advences in Pharmacological Siences, v.13, p.1-11, 2013.

WALLACE, R. J. Antimicrobial properties of plant secondary metabolites. Proceedings of the nutrition society, v.63, p.621-629, 2004.

WANG, C.J.; WANG, S.P.; ZHOU, H. Influences of flavomycin, ropadiar and saponins on nutrient digestibility, rumen fermentation, and methane emission from sheep. Animal Feed Science and Technology, v.148, p.157-166, 2009.

Receipt date: $01 / 05 / 2017$

Approval date: 21/05/2018 